\title{
An Eco-Theological interpretation of Proverbs 5:15-20 in the light of water crises experienced in present-day Africa
}

\author{
Kivatsi Jonathan KaVusa (University Of Pretoria)
}

\begin{abstract}
Proverbs 5:15-20 is not about ecological issues such as water management. However, the biblical author employed water-related metaphors as a way of speaking about faithfulness in marriage. The young man is instructed to drink water from his own cistern/well and to restrain himself from wasting this precious resource on the public areas ( $v v .15-16)$. This article explores attitudes or assumptions towards water that might have informed the author's use of water-related metaphors in an attempt to promote fidelity in marriage. The water management metaphors in Prov 5:15-20 are relevant in contemporary Africa, where water crises have developed not necessarily because of a lack of resources, but often because of issues related to poor water management. The investigation is facilitated by a hermeneutics of suspicion and retrieval or trust. Two of the six eco-justice principles associated with the Earth Bible Project are applied, namely the principles of intrinsic worth and interconnectedness.
\end{abstract}

KEYWORDS: Proverbs 5; cisterns; wells; water metaphors; ecological hermeneutics; eco-justice.

\section{A INTRODUCTION}

Africa is naturally blessed with great water resources: large rivers include the Congo, Nile, Zambezi and Niger. However, the continent is the second driest region in the world after Australia, and millions of Africans still suffer from water shortages as well as water-related diseases. ${ }^{1}$ Shortages are often the result of issues of uneven distribution or management - very often there is a great

* Article submitted: 17/03/2017; peer-reviewed: 26/04/2017; accepted: 17/08/2017. Kivatsi Jonathan Kavusa, "An Eco-Theological Interpretation of Proverbs 5:15-20 in the Light of Water Crises Experienced in Present-Day Africa," OTE 30 no. 3 (2017): 707-724. DOI: https://doi.org/10.17159/2312-3621/2017/v30n3a10

1 World Wildlife Fund, "The Facts of Water in Africa," 1, online: https: //www.google.com/search?q=www.panda.org\%2Flivingwaters\&client=aff-maxthonmaxthon $4 \&$ channel $=\mathrm{t} 28 \#$ channel $=\mathrm{t} 28 \& \mathrm{q}=$ millions + of + Africans + still + suffer + from $+\mathrm{w}$ ater+shortages+wwf. 
deal of water where there are fewer people - and to poor maintenance checks of existing supplies.

On 22 March 2011, the United Nations Environment Program (UNEP) released a report that an estimated 51 million people in the Democratic Republic of the Congo (DRC) - or three-quarters of the population - have no access to safe drinking water, although the country holds over half of Africa's water reserves. ${ }^{2}$ This situation is mostly a consequence of lack of expertise and political will, but there have also been allegations of mismanagement and corruption.

Referring to the necessity for good water management in South Africa, the Rainwater Harvesting Organization declared that:

South Africa is currently facing a multi-faceted water crisis. The mismatch between water supply and water demand, the theft of water resources, a deteriorating infrastructure, the loss of essential skills, a strangling educational pipeline, management failure, and deterioration in the quality of water, are all potential threats and key concerns [facing the country]. ${ }^{3}$

The issue is so vital that it cannot be left to natural sciences alone to deal with, but must be addressed with an interdisciplinary focus. The sustainable future of the planet requires the inputs of interdisciplinary approaches to water management. ${ }^{4}$ This article is a contribution from the fields of theology and biblical interpretation to address this problem. I present an ecological interpretation of Prov 5:15-20 in light of water crises experienced in present-day Africa.

Proverbs 5:15-20 is not about ecological issues such as water management. However, its use of water-related metaphors as a way of speaking about faithfulness in marriage is ecologically insightful. The young man is commanded to drink water from his own cistern/well and to prevent the water from his own fountains/springs from flowing into the streets and public places (vv. 1518). Management of water is a crucial metaphor in this text. As such, this text can be relevant in the context of modern Africa where water crises have developed not necessarily because of a lack of water resources, but often because of issues related to poor water management. The necessity of water for the surviv-

2 See UNEP, "In Water-Rich DR Congo: 50 Million People Lack Clean Water to Drink - UN," UN News Centre, online: http://www.un.org/apps/news/story.asp?News

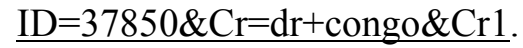

3 See Rainwater Harvesting (Gauteng \& NW Province), "South Africa's water resources under immense pressure," online: http://www.rainwaterharvesting .co.za/2016/06/03/south-africas-water-resources-under-immense-pressure-2/.

4 Barbara R. Johnston, "Preface," in Water, Cultural Diversity, and Global Environmental Change: Emerging Trends, Sustainable Futures?, ed. Barbara R. Johnston (London: UNESCO, 2012), xx. 
al of humans and animals, and the limited sources available in biblical times, made water and water management the commonest metaphor in the Bible. ${ }^{5}$

A number of studies have shown that the metaphor of Prov 5:15-20 is that of a father seeking to convince his son that genuine sexual happiness is to be found within marriage. ${ }^{6}$ While concurring with this erotic interpretation, this article set out to retrieve the ecological wisdom of the water metaphor in Prov 5:15-20. The question is: what assumptions about or attitudes towards water are reflected in the author's use of water-management metaphors in an attempt to promote faithfulness in marriage?

The answer to this question hinges on the perceptions that the author might have had regarding the value or the intrinsic worth of water in an arid land like Palestine. Indeed, the text is anthropocentric. However, the metaphor of a wife as cistern and well (v. 15) offers a means of understanding the text's perceptions of the value of water kept in reliable containers. The injunction to prevent the water from one's own springs/fountains from spreading into public areas (vv. 16-18) implies an awareness of the need for sustainable use of this resource. In a society whose economy is dependent upon agriculture, proper management of water is crucial.

\section{B BRIEF OVERVIEW OF APPROACHES TO PROVERBS 5:15-20}

\section{Feminist approaches to the text}

Feminist readings ${ }^{7}$ regard the metaphor as a clear remnant of patriarchy in which female images are passive and "stationary/inert" (cistern and well) in contrast to the dynamic male images (springs, fountains and streams). Fontaine argues that "the well, the jar, and the cistern furnish a comforting, female solution: inert, made and maintained by male effort, they contribute stability to the flow as they encompass the male streams." 8

5 Philip J. King and Lawrence E. Stager, Life in Biblical Israel (Louisville: Westminster John Knox, 2001), 122.

6 Richard J. Clifford, Proverbs: A Commentary (Louisville: Westminster John Knox Press, 1999), 66-72; Robert B. Chisholm, "Drink Water from Your Own Cistern: A Literary Study of Proverbs 5:15-23," BSac 157 (2000): 397-409; Carole R. Fontaine, "Visual Metaphors and Proverbs 5:15-20: Some Archaeological Reflections on Gendered Iconography," in Seeking the Wisdom of the Ancient: Essays Offered to Honour Michael V. Fox on the Occasion of his Sixty-Fifth Birthday, ed. Ron Troxel, Kelvin G. Friebel, and Dennis R. Magary (Winona Lake, IN: Eisenbrauns, 2005), 198-201.

7 See Milton P. Horne, Proverbs-Ecclesiastes, SHBC (Macon, GA: Smyth \& Helwys, 2003), 97; see also Fontaine, "Visual Metaphors," 198-201.

8 Fontaine, "Visual Metaphors," 201. 
710 Kavusa, "Proverbs in light of water crises," OTE 30/3 (2017): 707-724

The metaphor thus reflects a kind of stereotypical male language in which the male gender is normative and is the owner of the female, which is a mere object. ${ }^{9}$ In short, the female element in the metaphor is reduced to the level of an instrumental resource in the service of the master of the water kept in the cistern/well. The gendered images of the female body as stone, clay or flesh receptacles derive from patriarchal fantasies of control. ${ }^{10}$ However, feminist readings do acknowledge that the metaphor embodies views about sexuality in marriage.

\section{$2 \quad$ Erotic Reading of the Text}

It is generally accepted that Prov 5:15-20 commands faithfulness in marriage. Fox ${ }^{11}$ states that the metaphor of cistern/well refers to "cool, limpid refreshment for hot desires, which are satisfied by 'drinking,' that is, lovemaking." Modern commentaries regard the text as a motivation for faithful sexual intimacy in marriage. ${ }^{12}$ Attention is often devoted to what specifically the cistern and well images as well as the spring and fountain metaphors designate within marriage. For Clifford ${ }^{13}$, the cistern and well point to female sexuality, while the springs and fountains refer to man's semen (vv. 16-17).

\section{OUR APPROACH TO THE TEXT}

This article accepts these erotic readings, but rather focuses on retrieving the ecological dimensions of the metaphor. The question is why the author found the metaphor of cistern/well (v. 15) and spring/fountain streams (vv. 16-17) as such an appropriate vehicle to teach about fidelity in marriage. Furthermore, what assumptions about or attitudes towards water are reflected in the writer's use of water management metaphors in an attempt to promote faithfulness in marriage? To my knowledge, no study on Prov 5:15-20 has scrutinized this particular question.

Adopting a hermeneutics of suspicion and retrieval, this article makes use of the principles of intrinsic worth and interconnectedness, two of six eco-

\footnotetext{
9 Horne, Proberbs, 97.

10 Fontaine, "Visual Metaphors," 202.

11 Michael V. Fox, Proverbs 1-9: A New Translation with Introduction and Commentary (New York: Doubleday, 2000), 199.

12 See Tremper Longman III, Proverbs (Grand Rapids, MI: Baker Academic, 2006), 161; Katharine J. Dell, The Book of Proverbs in Social and Theological Context (New York: Cambridge University Press, 2006), 41-42.

13 Clifford, Proverbs, 68.
} 
justice $^{14}$ principles of the Earth Bible Project to unlock the ecological wisdom implicit in Prov 5:15-20. Suspicion here implies that the reader suspects that biblical texts, written by human beings for human readers, primarily reflect human interests. ${ }^{15}$

By adopting a hermeneutics of retrieval or trust, the present article focuses on features of the text that can enable the recovery of insights about the intrinsic value of water from the metaphorical mode of Prov 5:15-20. The water-related metaphors in the text may contain ecological wisdom that has gone unnoticed, silenced or ignored in anthropocentric readings of the text.

The principle of intrinsic worth/value suggests that "the universe, Earth and all its components have value in themselves, not only because they are useful for humans." 16 The principle of interconnectedness, in turn, presumes that all elements of the universe are interconnected.

\section{METAPHOR THEORY APPLIED TO PROVERBS 5:15-20}

A metaphor consists of a vehicle, a referent and a tenor. ${ }^{17}$ The tenor links the vehicle and the referent. ${ }^{18}$ In Prov 5:15-20, the cistern and well are vehicles for a wife, while springs/fountain streams are vehicles for the man's semen. Sexual intimacy within marriage is the referent, which is linked to the vehicle through the tenor. The tenor concerns elements of the vehicle (cistern/well and springs/fountain) that invite particular understandings of the referent (erotic love). The tenor of the cisterns/wells refers to their state as water containers, while the tenor of springs/fountains relates to their natural preciousness.

The aim of the present article is thus to interpret the water management metaphor in Prov 5:15-20 in order to reveal the ecological insights contained within those water-related images as pertaining to the imagination of the "erotic world" of Prov 5:15-20.

14 The six eco-justice principles can be found in Norman C. Habel, "Introducing Ecological Hermeneutics," in Exploring Ecological Hermeneutics, ed. Norman C. Habel and Peter Trudinger (Atlanta: Society of Biblical Literature, 2008), 2.

15 The Earth Bible Team, "Guiding Ecojustice Principles," in Reading from the Perspective of Earth, ed. Norman C. Habel (Sheffield: Sheffield Academic, 2000), 39.

16 Habel, "Introducing," 2.

17 For more details about metaphor theory, see Göran Eidevall, Grapes in the Desert: Metaphors, Models, and Themes in Hosea 4-14 (Stockholm: Almqvit \& Wiksell International, 1996), 19-25.

18 Roland Boer, "Keeping it Literal: The Economy of the Song of Songs," JHebS 7/6 (2007), 14 pages, doi: 10.5508/jhs.2007.v7.a6. 
712 Kavusa, "Proverbs in light of water crises," OTE 30/3 (2017): 707-724

\section{E LITERARY MATTERS OF PROVERBS 5:15-20}

\section{Translation of Proverbs 5:15-20}

The following translation is drawn from the NRSV, except for v. 16, which is the fruit of my critical analysis.

${ }^{15}$ Drink water from your own cistern, flowing water from your own well.

${ }^{16}$ How should your springs be scattered abroad, streams of water in the streets? ${ }^{19}$

${ }^{17}$ Let them be for yourself alone, and not for sharing with strangers.

${ }^{18}$ Let your fountain be blessed, and rejoice in the wife of your youth,

${ }^{19}$ A lovely deer, a graceful doe.

May her breasts satisfy you at all times;

May you be intoxicated always by her love.

${ }^{20}$ Why should you be intoxicated, my son, by another woman and embrace the bosom of an adulteress?

\section{The literary position of Proverbs 5:15-20}

It is widely agreed that the book of Proverbs is by nature a collection of sayings from anonymous and innumerable sages over a number of generations, at a minimum from Solomon's reign (10th century $\mathrm{BCE}$ ) to somewhere during the exile or the postexilic (Persian and Hellenistic) eras, but before Ben Sira (2nd

19 The jussive verb (יפוּצו) in the MT (Let your springs flow into the streets) would contradict v. 15 confining sex in the limits of marriage. The LXX has altered the verse as "lest your springs (wife) overflow in public like rivulets in the open streets." For the LXX, a wife may satisfy or attract many men just like a prostitute (see Chisholm, "Drink Water," 400). This reading infers that a husband's unfaithfulness can lead his wife to adultery (see the French Bible La Bible en Français Courant stating "Ne laisse pas son eau couler dans les rues et se disperser sur les places publiques"). This translation is in contrast with v. 15. Given the problem, others have rendered v. 16 as a result: "and so your spring will flow..." reading springs and fountains as offspring. It is understood that if someone restricts sex to marriage, he will have legitimate children (not bastards) in the community (see the Complete Jewish Bible: "Let what your springs produce be dispersed outside, streams of water flowing in the streets"). This reading is dubious, because nowhere in the Bible do springs and fountains refer to descendants. This article concurs with scholars who view Prov 5:16 as a rhetorical question introduced by איך ("how should" or simply "should your springs," see v. 12), which was probably overlooked due to an error of haplography since the preceding בארד (your well, v. 15b). See Patrick W. Skehan, "Proverbs 5:5-19 and 6:2024," CBQ 8/3 (1946): 290-297. 
century BCE). ${ }^{20}$ The book is therefore not a single unified composition, ${ }^{21}$ but an anthology of different works consisting of poems, instructions, speeches and a number of sayings dispersed over several collections. ${ }^{22}$

Prov 1-9, which is the original literary context of Prov 5:15-20, constitutes the first section of the book. This section, which comprises twelve wisdom poems, ${ }^{23}$ may have formerly stood as an independent book prior to the editorial composition. ${ }^{24}$ It is considered as the latest redaction because of its precise educational form and its strict view of certain sins (adultery/robbery) as well as its status as a kind of introductory ${ }^{25}$ framework within which to read the rest of the book. ${ }^{26}$ Its poems do not display a logical flow of thought from one poem to another; rather, they address the issue of seduction from different angles and through distinct rhetorical strategies. ${ }^{27}$

20 For further details on the composition of Proverbs, see Crawford H. Toy, Critical and Exegetical Commentary on the Book of Proverbs (Edinburgh: T\&T Clark, 1977), xix-xxxi.

21 The title "Proverbs of Solomon" does not claim that Solomon was the "author" of the book in the modern sense of the term, but is in accordance with the ANE principle of honorary and pseudepigraphic authorship. The title of the work (Prov 1:1) is similar to that of Egyptian instructional texts, which include the name of the author/compiler formulated in the third person with epithets. In this sense, these titles not only refer to the author of the work, but also identify the voice that is heard throughout the document. The notice "Solomon son of David" (1:1) implies that editors might have included it to clarify the identity of the speaker in the document. For an interesting discussion of various forms of authorship in the ANE, see Karel van der Toorn, Scribal Culture and the Making of the Hebrew Bible (Cambridge: Harvard University Press, 2007), 27-49.

22 Proverbs 1:1-9:18; 10:1-22:16; 22:17-24:22; 24:23-34; 25:1-29:27; 30:1-33; and 31:1-31. For more details, see Bruce K. Waltke, The Book of Proverbs: Chapters 1-15 (Grand Rapids, MI: Eerdmans, 2004), 9-27.

23 Ten lectures of the father to his son (Prov 1:8-19; 2:1-22; 3:1-12, 13-35; 4:1-9, 10 $19,20-27 ; 5: 1-23 ; 6: 1-19 ; 6: 20-35 ; 7: 1-27)$ and two interludes, extended addresses of the woman wisdom (Prov 1:20-33; 8:1-36).

24 However, some have argued for an earlier dating for the section, or at least for the presence of older concepts, genres and material within it. Given that the book is a collection or series of collections, a distinction needs to be made between oral and written stages of materials, which may have formerly existed in a context before the one in which they now appear. See Dell, Proverbs, 18.

25 The heading "The proverbs of Solomon son of David, king of Israel," (Prov 1:1) is the title not only of chs. 1-9 but also of the entire book (Clifford, Proverbs, 1).

26 Fox, Proverbs 1-9, 7.

27 Christopher B. Ansberry, Be Wise, my Son, and Make my Heart Glad: An Exploration of the Courtly Nature of the Book of Proverbs (Berlin: De Gruyter, 2011), 44. 
714 Kavusa, "Proverbs in light of water crises," OTE 30/3 (2017): 707-724

The intention is to prepare young people to face the problems and dangers of the adult world so that they may become wise and responsible. ${ }^{28}$ This refers precisely to Proverbs that has the nature of instructions from parents to son (or from teacher to pupil) about how to make the right choices and follow the way of wisdom and life rather than the way to folly and death. ${ }^{29}$ It is therefore deliberate that Prov 3:1-4:27 and Prov 5:1-6:35 appear in the centre of Prov 1-9, commanding the listeners to heed the teaching and to warn against adulterous sex, respectively. ${ }^{30}$

Several scholars ${ }^{31}$ have convincingly argued that Prov 5:1-20, involving teachings from father/teacher to son/pupil to avoid extramarital sexual relationship, is a distinct literary unit, which is linked to Prov 6:1-19 by an editorial addition of Prov 5:21-23. ${ }^{32}$ It is understood that apart from the introduction (Prov 5:1) and the editorial concluding remarks (Prov 5:21-23), Prov 5:1-20 present two opposite speeches: the one commanding avoidance of liaisons with harlots whose way leads to Sheol (Prov 5:2-14), and the other (Prov 5:15-20) advising faithfulness in marriage.

Through the effective use of water-related metaphors, the son's wife in Prov 5:15-20 is described as an appropriate receptacle (cistern and well) of trustworthy water to drink, while the male semen is envisaged as springs, streams of water and fountains that should not be spilled or wasted on public areas with harlots (vv. 15-18). In both cases, water-related motifs are vehicles in the service of an anthropocentrism related to sexuality in marriage.

\section{$3 \quad$ Literary Structure of Proverbs 5:15-20}

A Drink water from your own cistern/well, v. 15ab

B Should your springs/fountains be scattered abroad? v. 16ab

$\mathrm{B}^{\prime} \quad$ Let them be for you alone, and let them be blessed, vv. 17-18a

$\mathrm{A}^{\prime} \quad$ Be intoxicated by (or Rejoice in) your wife, vv. 18b-20

28 Roger N. Whybray, The Composition of the Book of Proverbs (Sheffield: Sheffield Academic Press, 1994), 11.

29 Dell, Proverbs, 22.

30 For the schematic structure of Prov 1-9, see Waltke, Proverbs, 12.

31 It is generally agreed that Prov 5:15-20 are the climactic verses in ch. 5 of Proverbs, while vv. 21-23 are considered as final editorial additions similar to what is found at the end of chs. 1, 2 and 3 (see Toy, Proverbs, 116.

32 Fox refutes the argument of editorial addition, arguing that vv. 21-23 might have existed as independent proverbs before being combined and applied to vv. 15-20 (see Fox, Proverbs 1-9, 204). It should be admitted that the religious reward of sin in vv. 21-23 is a new idea here which must be regarded as an editorial addition. The book of Proverbs is full of such literary additions, either for theological or non-theological reasons. For examples, see Whybray, Proverbs, 11. 
The structure is an alternating parallelism. AA' are employed in a way that water-related metaphors of cistern/well in A point to the idea of being intoxicated by one's wife in A'. The imperative to "drink water (שְתתה־מַים v. v. 15) from your own cistern/well" is used as a synonym of being intoxicated (תִשֶׁג, v. 19) by your wife in the sense of becoming drunk from drinking your wife's water. That is why the piel (intensive form) ירוּרוּ (from the root) literarily refers to plenty of water in one's wife to quench one's thirst all the time and always (v. 19). The ecological significance of this statement is discussed later.

In contrast, the water-related metaphors of springs/fountains (water that is naturally flowing without human effort) in B point to the idea of responsible water management reflected in B'. Despite the fact that springs and fountain streams are produced by natural means, it is assumed that they may not last forever, or that they can be wasted. In this sense, B is a rhetorical question assuming a No answer, which is further commented in B' that water should be consumed within specific limits. While the lines AA' relate to one's wife's sexuality as imaged by the cistern/well, BB' refer to male sexuality (semen) as natural water that should be managed properly.

\section{F RETRIEVING THE ECOLOGICAL WISDOM IN PROVERBS 5:15-20}

1 Drink water from your own cistern/well (v. 15a)

\section{1a Cisterns and wells in the Old Testament}

Prior to the Late Bronze Age (2000-1500 BCE), people in Palestine inhabited only the Jordan valley, where life was sustainable because of the presence of water for livestock and agriculture. ${ }^{33}$ Later, humans flourished in arid areas by making cisterns to store rainfall or digging wells to contain groundwater. Because of the scarcity of rainfall, such wells and cisterns were vitally important for the people in a city or a village. ${ }^{34}$ In this sense, the well was the common meeting place of the village, central to the social and economic life of a community. ${ }^{35}$

It was therefore the responsibility of the $\operatorname{king}^{36}$ to dig and maintain in good condition the public well for a city (Num 21:18). However, given that

33 Philippe Reymond, L'eau, sa Vie et sa Signification dans l'Ancien Testament (Leiden: Brill, 158), 123.

34 T. J. Jones, Quelle, Brunnen und Cisternen im Alte Testament (Leipzig: Pfeiffer, 1928), 6 .

35 King and Stager, Life, 124.

36 See Hezekiah's efforts to secure a water supply in 2 Chr 32:2-5. 
wells could not be drilled everywhere, the making of cisterns was a considerable development that boosted human settlement, especially in places where perennial streams and other water sources were not numerous, reliable or voluminous. ${ }^{37}$

Cisterns were used either to supplement the water supply during the summer (when wells and sources dried up), or they acted as wells - as public property - in places where it was difficult to dig a well. ${ }^{38}$ The advantage of a cistern is that it can be made anywhere (in gardens, fields, deserts, at home) with all kinds of dimensions, since the issue of depth does not apply.

Cisterns and wells required thorough maintenance checks in order to keep them in good condition, otherwise they could become useless. In this sense, without naming the origin of the fractures, Jer 2:13 explains how the broken cisterns (בּרוֹת נְשׁׁברוֹת) are useless: they cannot hold or maintain water. Builders of wells made the well-mouths narrow (2 Sam 17:19 and Prov 18:27) in order to prevent people and animals from falling in, and to keep water fresh (Jer 6:7), free from contamination, and to minimize evaporation. ${ }^{39}$

Moreover, cisterns and wells involved hard work as indicated by several Hebrew verbs used with reference to their making (חפר, to drill in Gen 21:30

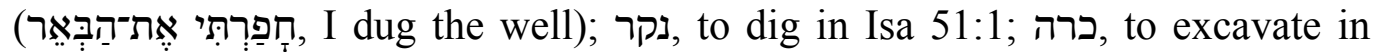
Gen 26:25 and Num 21:18; Exod 21:33). As it was hard to make a cistern, one can understand why the authors of Deut 6:11 considered it a privilege for Israel to take possession of a country in which a number of cisterns were already available. In arid Palestine, it was not the flowing water that was important, but the rainfall water caught in cisterns and freshwater kept in wells hewn into bedrock by hard labor. ${ }^{40}$

37 The invention of cisterns increased the Israelites' presence all over the regions of Palestine, whereas the Canaanites, dependent on natural flows of water, were confined to limited areas. See Roger W. Hamilton, "Water Works," IDB 4 (1962): 812.

38 Reymond, L'eau, sa Vie, 134.

39 That is why the owners of private cisterns made sure of all the maintenance checks (clearing of silt, plastering of cracks, and repairing of feeder channels) to avoid water depletion. See Daniel Hillel, The Natural History of the Bible: An Environmental Exploration of the Hebrew Scriptures (New York: Columbian University Press, 2006), 57.

40 In the south of Palestine (Arad, Kadesh Barnea, Beth-shemesh, Tel-sheva) cisterns were cut directly into bedrock in the shape of a bottle or bell, and in regions where rocks were porous, cisterns had to be plastered with lime in order to hold water successfully (see Fontaine, "Visual Metaphors," 198). In contrast, in the north of the country (Gibeon, Hazor, Gezer, Meggido) cistern-makers cut directly into the bedrock to reach the water table. 


\section{1b The ecological significance of the cistern/well metaphor (v. 15ab)}

\section{(i) Poverty and absence of water sanitation}

It is currently argued that poverty is the crucial factor hindering the sustainable provision of basic water and sanitation services. The text of Prov 5:15 reflects the $8^{\text {th }}$ century $\mathrm{BCE}$, when private cisterns were found in homes in contrast to public cisterns. ${ }^{41}$ Given the hard work and regular maintenance checks involved in keeping a cistern, it is clear that owning a private cistern is an indication of wealth. Poverty impedes access to clean water, while access to clean water improves the lives of the beneficiaries. ${ }^{42}$

In contrast to Egypt, where agriculture and daily life were based on irrigation from the Nile, most of Israel's welfare depended upon seasonal rainfalls captured in cisterns. Those who owned cisterns in their homes thus had a privileged life. The phrase "you will drink water from your own cistern" in $2 \mathrm{Kgs}$ $18: 31$ is an expression of stability and wealth. In this sense, water scarcity during wars had a more disastrous impact on the poor than on the wealthy. ${ }^{43}$

In the Moabite stone inscription, King Mesha boasted about having championed the initiative of owning private cisterns in one's house ${ }^{44}$. In so doing, Mesha claims that he facilitated wealth in the midst of his people as follows:

It was I [Mesha] (who) built Qarhoh, the wall of the forests and the wall of the citadel; I also built its gates and I built its towers and I built the king's house, and I made both of its reservoirs for water inside the town. And there was no cistern inside the town at Qarhoh, so I said to all the people, "Let each of you make (25) a cistern for himself in his house!" And I cut beams for Qarhoh with Israelite captives. I built Aroer, and I made the highway in the Arnon (valley); I built Beth-bamoth, for it had been destroyed; I built Bezer for it lay in ruins - with fifty men of Dibon, for all Dibon is (my) loyal dependency. ${ }^{45}$

41 Fontaine, "Visual Metaphors," 200.

42 That is why upgrading the irrigation water systems and the making of cisterns are among the initiatives for reducing poverty in modern Palestine. See United Nations Development Program of Assistance to the Palestinian People (UNDP/PAPP), "Poverty Reduction and Economic Empowerment," 2, online: http://www.ps.undp.org /content/dam/papp/docs/Publications/UNDP-papp-research-facts-poverty.pdf.

43 King and Stager, Life, 122.

44 William F. Albright, "Palestinian Inscriptions: Moabite Stone," ANET, 320.

45 Albright, "Palestinian Inscriptions," 320-321. 
718 Kavusa, "Proverbs in light of water crises," OTE 30/3 (2017): 707-724

This inscription shows that there is a connection between poverty and water access.

(ii) Cistern/Well: Water Always Available

The command שִתתה־מָימים (to drink water) has an erotic meaning as in Song 4:15: "you are a garden spring, a well of living water, and springs from Lebanon." However, the words מִבּוֹרִּ (from your own cistern) and בְּאר (from your own well) confine the drinking of water to individual reservoirs. There are formally two metaphors for one's wife's sexuality: a cistern (בּ), which is a reservoir/container of water, and a well (באר), which is a source of water continually refilled by underground springs. ${ }^{46}$ The son's wife is thus both a well and a cistern, a basic source of water (well) and a supplementary source of water (cistern).

Ecologically speaking, there is no need to go outside for water. In this sense, v. 19 encourages the husband to be intoxicated by his wife "all the times" (בְכל־-עֵת) and "always" (תָמִיד), a wife being both a well of living water

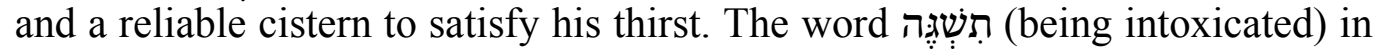
v. 19 literally means "unable to walk straight" and is connected to the expres-

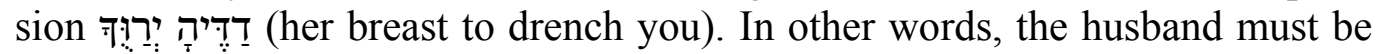
dependent on the water of his own container.

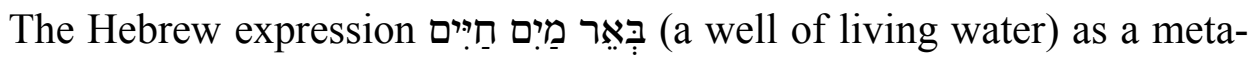
phor for one's wife implies that with a well, the quality of water supply was assured even in the time of drought. The words מִבּרְר (from your own cistern)

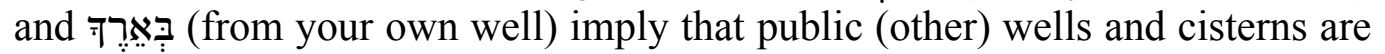
not trustworthy and thus dangerous. To encourage faithfulness, an African proverb states that "Foreign water does not quench thirst" (Nande, DRC). That is why Prov 23:27 depicts the prostitute as a deep pit (שרוּה (27 $^{47}$ and a narrow well in the sense of being a potential threat. It should be stated here that sometimes cisterns/pits and wells were used as prisons, since one could not get out of them without the help of others (Gen 37:20; Isa 24:22; Zech 9:11).

The metaphor of the wife as the son's cistern/well reinforces the intrinsic value of water that should be contained and preserved in a reliable private receptacle, in contrast to public vessels accessible to everybody. The wife is here presumed to be unique, like no one else and as embodying a substance not to be shared with others. ${ }^{48}$ Water is essential for life and, therefore, it should be valued and carefully managed under reliable conditions.

46 Fox, Proverbs 1-9, 199.

47 A pit was also used for trapping animals (Jer 2:6).

48 Clifford, Proverbs, 72. 
Kavusa, "Proverbs in light of water crises," OTE 30/3 (2017): 707-724

\section{$2 \quad$ Avoid wasting the water of your springs/fountains (vv. 16-17)}

\section{2a Springs and fountains in the Old Testament}

Springs consist of natural outflows of underground water ${ }^{49}$ on the surface of earth, where the underground water-resistant rock level meets the ground surface. A well is thus an artificial - or better, human - attempt to tap the same groundwater brought to the surface naturally in a spring. ${ }^{50}$ Despite being part of tehom, springs and fountain streams represent the positive aspect of tehom, ${ }^{51}$ as they provide the earth's surface with life-giving and controlled underground water. ${ }^{52}$ Good use of this natural blessing involved the building of terrace systems below the springs/fountains for the purpose of irrigation. ${ }^{53}$

However, topographically, most streams in Canaan were ephemeral, flowing a few hours after each rainfall in the Negev, a few days in the Judean Highlands, and a few weeks or months in the north of the country. Even the perennial streams that were nurtured by runoff or groundwater renewed by seasonal precipitation, declined to drips during the summer. ${ }^{54}$ One can understand why Prov 5:16 forbids sexual infidelity through the metaphor of useless scattering of this scarce natural resource. Feliks asserts that "there is no evidence that in ancient times there were more than the hundreds of small springs and the few moderate and large fountains which now exist." 55

49 It is attested in the main creation accounts on the ANE that water pre-existed the earth. In Gen 1:6-10, the created order resulted from the separation of the primal waters into water above the dome (רקע) and the lower waters, including the seas and underground waters. The lower waters were referred to as the primeval flood, the deep or chaos water (tehom), which constantly threatened to break out and turn the cosmos into chaos. See the comments of Ronald Simkins, Yahweh's Activity in History and Nature in the Book of Joel (Lewiston: The Edwin Mellen Press, 1991), 108-109.

50 David C. Hopkins, The Highlands of Canaan: An Agricultural Life in the Early Iron Age (Sheffield: JSOT Press/Almond Press, 1985), 96.

51 There is a great debate about the association of Tiamat and tehôm. This is not the place to argue for or against any perspective. This article agrees with the idea that both words Tiamat and tehôm, along with other Babylonian terms such as tiamtu or tamtu, derive from the Semitic root thm and mean ocean, sea or deep, the primeval waters constituting a potential threat for the earth. See Alexander Heidel, The Babylonian Genesis (Chicago: Phoenix Book, 1963), 100.

52 Frances Klopper, "The Rhetoric of Conflicting Metaphors: A Fountain Desired in the Song of Songs but Abhorred in Leviticus," OTE 15/3 (2002): 676.

53 Gershon Edelstein and Shimon Gibson, "Ancient Jerusalem's Rural Food Basket," BAR 8/1 (1982): 52.

54 Efraim Orni and Elisha Efrat, Geography of Israel, 3rd ed. (Philadelphia: Jewish Publication Society, 1973), 441-442.

55 Jehuda Feliks, “Agriculture in the Land of Israel," EncJud 2 (1971): 388. 
Most streams in Canaan had sharply carved a fixed course through the limestone where they regularly flow. Therefore, naturally, the extent of areas irrigable by fountain streams remained strictly limited. ${ }^{56}$ This factor constrained farming activities in other areas where water was captured, distributed and stored during the seasonal flow of the streams.

\section{2b Ecological Significance of the Metaphor in vv. 16-18}

The literary problem of v. 16 as it appears in the MT has been discussed earlier. This article accepts the translation of spring and fountain streams as referring to the husband's sexuality. The article further assumes that v. 16 is a rhetorical question expecting a No answer as follows: "should your springs flow into the streets?"

The warning against the spilling of the springs and streams of water on the streets and squares offers insightful ecological wisdom. The instruction of Prov 5:16 might reflect the fact that just as most of Canaan's streams had carved a fixed course through the limestone where they regularly flowed, so the husband should restrict his semen for his wife. The warning is thus against the useless spilling of this valuable natural water resource. The image of scattering does not therefore imply the increase of water, but wasting it on the streets.

The streets (חרוּצָה) and (רחוֹת) were the public places for harlots or prostitutes. ${ }^{57}$ The warning "should your springs..." thus condemns the spilling of valuable spring or fountain waters on the city plazas where it is wasted, whereas they could be wisely managed in the son's well and cisterns of v. 15 . Proverbs 5:9-10 supports this interpretation, mentioning that sexual liaison with the harlot drains the man's vigor and wealth. This means that while the woman of Prov 5:8-10 manipulates, counterfeits and steals "her clients," one's wife (vv. 15-19) is genuine, loving and protects her husband. ${ }^{58}$

Ecologically speaking, this implies that water stored in the private cistern/well (v. 15) is positively connected with the man's life in terms of health and wealth, while the contrast (spring water spilled in the streets) is understood as mismanagement, or as giving "your honour to others, and your years to the merciless" (Prov 5:9). The dryness of the desert related to water scarcity may have informed Prov 5:16 to express the need for careful management of the available resources in this metaphor. A parallel Arabian metaphor states:

\footnotetext{
56 Hopkins, Highlands, 95.

57 Waltke, Proverbs, 319.

58 Clifford, Proverbs, 71.
} 
"Don't pour away your water on the strength of a mirage." 59 The rhetorical idea behind Prov 5:16 is that adultery will lead, inter alia, to impotence.

In more ecological terms, the wrong attitudes towards water resources will lead, among others, to water depletion. That is why the legislation on water in modern Israel states that "a person's right to receive water is valid as long as its receipt does not lead to its salination or depletion." 60 In a land in which water is scarce, and where cisterns are built to store every drop of rainwater for the sake of irrigation and survival, the restriction to avoid scattering water uselessly reveals that water is considered as:

Quelque chose de bon, d'utile, mais aussi comme quelque chose dont on risque facilement de manquer. ${ }^{61}$

Proverbs 5:16 is informed by the principle of the intrinsic worth of water that had to be used sustainably. Useless spilling of water on the streets represent a disrespectful attitude to water and testifies to ignorance about the notion of sustainability. That is why, in many ancient civilizations, water management was part of the royal code of the empire to the point that:

To spurn or disrespect the waters was an insult, an act of defiance against a figure of authority with the power to punish. ${ }^{62}$

In this sense, v. 17a and v. $18 \mathrm{a}$ are used in a synonymous parallelism. The advice "let them be for you alone" is synonymous with "let your fountains be blessed." Both verses allude to the better use of water from the springs. Without stressing it, they imply that the proper places for "spilling" the springs and streams of water are one's own cistern and well of v. 15, where they are a blessing (ברוּך). It should be said here that the verb ברך does not allude to children, ${ }^{63}$ but to sensual enjoyment. The basis for the text is rather Isa 36:16, where "drinking from one's cistern" is a sign of wealth and blessing. ${ }^{64}$

59 Martin H. Manser, The Facts on File Dictionary of Proverbs: Meaning and Origins of More than 1,700 Popular Sayings, 2nd ed. (New York: Facts on File, 2007), 11.

60 See "Israeli Water Law 1959," page 1, online: http://www.sviva.gov.il/English /Legislation/Documents/Water\%20Laws\%20and\%20Regulations/WaterLaw1959-

Excerpts.pdf.

61 English translation: water is considered as something good, useful, but also as something that could easily be missed (see the original French statement in Reymond, L'eau, sa vie, 2).

62 Ruth A. Morgan and James L. Smith, "Premodern Streams of Thought in TwentyFirst-Century Water Management," RHRev 116 (2013): 109.

63 Fox, Proverbs 1-9, 201-202.

64 Toy, Proverbs, 112. 
722 Kavusa, "Proverbs in light of water crises," OTE 30/3 (2017): 707-724

The poem assumes an underlying principle of not wasting water. As springs and fountains were occasional and meagre, wrong attitudes towards the overflowing water from these scarce water supplies were unacceptable. Job 14:10-12 is aware that even perennial rivers may vanish, just as human beings die forever lifeless. Although springs and fountains bubble from inside the earth by natural means, they were never viewed as an infinite resource, but as things that require responsible attitudes.

\section{G CONCLUSION}

\section{Implications for Africa}

Water management is a critical issue in contemporary Africa. In many places, very old aqueducts endlessly scatter water on the streets because there have been no maintenance checks. Many people have to drink from unsafe sources, resulting in their suffering from water-related diseases such as bilharzia, malaria and typhoid. Poverty aggravates the matter even further.

The metaphor of Prov 5:15-20 implies three facts about water: firstly, water should be kept clean; secondly, water should not be used for wrong purpose or simply wasted; and thirdly, there is a link between poverty and lack of clean water.

These facts should be addressed at several levels. Firstly, at the personal level, there is a need to develop these attitudes in our homes. Secondly, there is a call to African governments to improve the wellbeing of their people so that they can drink from their "own well and cistern" instead of spending hours fetching water from distant sources. Thirdly, since water is part of God's gift, water management should be part of the church's teachings in this time of multiple water crises.

\section{$2 \quad$ Limits of the analysis}

The prescription in Prov 5:16 about "not sharing water" would fly in the face of contemporary ideals of extending water resources to regions in dire need. This would include, for instance, extending the River Congo to enrich Lake Chad.

However, it should be said that Prov 5:15-20 cannot be used to resolve all issues related to contemporary water crisis. As stated earlier, the text is not even about water, but uses water conservation metaphors to prohibit sexual infidelity.

\section{BIBLIOGRAPHY}

Ansberry, Christopher B. Be Wise, my Son, and Make my Heart Glad: An Exploration of the Courtly Nature of the Book of Proverbs. Berlin: De Gruyter, 2011. Albright, William F. "Palestinian Inscriptions: Moabite Stone.” ANET, 320-321. 
Kavusa, "Proverbs in light of water crises," OTE 30/3 (2017): 707-724

Boer, Roland. "Keeping it Literal: The Economy of the Song of Songs." JHebS 7/6 (2007), 14 pages. Doi: 10.5508/jhs.2007.v7.a6.

Chisholm, Robert B. "Drink Water from Your Own Cistern: A Literary Study of Proverbs 5:15-23.” BSac 157 (2000): 397-409.

Clifford, Richard J. Proverbs: A Commentary. Louisville: Westminster John Knox Press, 1999.

Dell, Katharine J. The Book of Proverbs in Social and Theological Context. New York: Cambridge University Press, 2006.

Earth Bible Team, The. "Guiding Ecojustice Principles." Pages 38-53 in Reading From the Perspective of Earth. Edited by Norman C. Habel. Sheffield: Sheffield Academic, 2000.

Edelstein, Gershon and Shimon Gibson. "Ancient Jerusalem's Rural Food Basket." BAR 8/1 (1982): 46-54.

Eidevall, Göran. Grapes in the Desert: Metaphors, Models, and Themes in Hosea 414. Stockholm: Almqvit \& Wiksell International, 1996.

Feliks, Jehuda. "Agriculture in the Land of Israel." EncJud 2 (1971): 382-398.

Fontaine, Carole R. "Visual Metaphors and Proverbs 5:15-20: Some Archaeological Reflections on Gendered Iconography." Pages 185-202 in Seeking the Wisdom of the Ancient: Essays Offered to Honour Michael V. Fox on the Occasion of his Sixty-Fifth Birthday. Edited by Ron Troxel, Kelvin G. Friebel and Dennis R. Magary. Winona Lake, IN: Eisenbrauns, 2005.

Fox, Michael V. Proverbs 1-9: A New Translation with Introduction and Commentary. New York: Doubleday, 2000.

Habel, Norman C. "Introducing Ecological Hermeneutics." Pages 1-8 in Exploring Ecological Hermeneutics. Edited by Norman C. Habel and Peter Trudinger. Atlanta: Society of Biblical Literature, 2008.

Hamilton, Roger W. "Water Works." IDB 4 (1962): 811-816.

Heidel, Alexander. The Babylonian Genesis. Chicago: Phoenix Book, 1963.

Hillel, Daniel. The Natural History of the Bible: An Environmental Exploration of the Hebrew Scriptures. New York: Columbian University Press, 2006.

Hopkins, David C. The Highlands of Canaan: An Agricultural Life in the Early Iron Age. Sheffield: JSOT Press/Almond Press, 1985.

Horne, Milton P. Proverbs-Ecclesiastes. SHBC. Macon, GA: Smyth \& Helwys, 2003.

"Israeli Water Law 1959." 12 pages. Online: http://www.sviva.gov.il/English /Legislation/Documents/Water\%20Laws\%20and\%20Regulations/WaterLaw195 9-Excerpts.pdf.

Johnston, Barbara R. "Preface." Pages XI-XXI in Water, Cultural Diversity, and Global Environmental Change: Emerging Trends, Sustainable Futures? Edited by Barbara R. Johnston. London: UNESCO, 2012.

Jones, T. J. Quelle, Brunnen und Cisternen im Alte Testament. Leipsig: Pfeiffer, 1928. King, Philip J. and Lawrence E. Stager. Life in Biblical Israel. Louisville:

Westminster John Knox, 2001.

Klopper, Frances. "The Rhetoric of Conflicting Metaphors: A Fountain Desired in the Song of Songs but Abhorred in Leviticus.” OTE 15/3 (2002): 675-686.

Longman III, Tremper, Proverbs. Grand Rapids, MI: Baker Academic, 2006.

Manser, Martin H. The Facts on File Dictionary of Proverbs: Meaning and Origins of More than 1,700 Popular Sayings. 2nd edition. New York: Facts on File, 2007. 
724 Kavusa, "Proverbs in light of water crises," OTE 30/3 (2017): 707-724

Morgan, Ruth A. and James L. Smith. "Premodern Streams of Thought in TwentyFirst-Century Water Management." RHRev 116 (2013): 105-129.

Orni, Efraim and Elisha Efrat. Geography of Israel. 3rd ed. Philadelphia: Jewish Publication Society, 1973.

Rainwater Harvesting (Gauteng \& NW Province). "South Africa's water resources under immense pressure." online: http://www.rainwaterharvesting.co.za /2016/06/03/south-africas-water-resources-under-immense-pressure-2/

Reymond, Philippe. L'eau, sa Vie et sa Signification dans l'Ancien Testament. Leiden: Brill, 1958.

Simkins, Ronald. Yahweh's Activity in History and Nature in the Book of Joel. Lewiston: The Edwin Mellen Press, 1991.

Skehan, Patrick W. "Proverbs 5:5-19 and 6:20-24." CBQ 8/3 (1946): 290-297.

Toy, Crawford H. Critical and Exegetical Commentary on the Book of Proverbs. Edinburgh: T\&T Clark, 1977.

UNEP. "In Water-Rich DR Congo: 50 Million People Lack Clean Water to Drink UN.” UN News Centre. Online: http://www.un.org/apps/news/story.asp ?NewsID $=37850 \& \mathrm{Cr}=\mathrm{dr}+$ congo\&Cr1.

United Nations Development Program of Assistance to the Palestinian People (UNDP/PAPP). "Poverty Reduction and Economic Empowerment." 2 pages. Online: http://www.ps.undp.org/content/dam/papp/docs/Publications/UNDPpapp-research-facts-poverty.pdf.

Van der Toorn, Karel. Scribal Culture and the Making of the Hebrew Bible. Cambridge: Harvard University Press, 2007.

Waltke, Bruce K. The Book of Proverbs: Chapters 1-15. Grand Rapids, MI: Eerdmans, 2004.

Whybray, Roger N. The Composition of the Book of Proverbs. Sheffield: Sheffield Academic Press, 1994.

World Wild Fund. "The Facts of Water in Africa." 2 pages. Online: https://www .google.com/search?q=www.panda.org\%2Flivingwaters\&client=aff-maxthonmaxthon $4 \&$ channel $=\mathrm{t} 28 \#$ channel $=\mathrm{t} 28 \& \mathrm{q}=$ millions $+\mathrm{of}+$ Africans + still + suffer $+\mathrm{fr}$ om+water+shortages+wwf.

Dr. K. Jonathan Kavusa is currently a postdoctoral researcher at the University of Pretoria, Department of Old Testament with Prof. Esias E. Meyer. Email: jokakiv@yahoo.fr. 